\title{
ROOT DISTRIBUTION OF ROOTSTOCKS FOR ‘TAHITI’ LIME
}

\author{
Carmen Silvia Vieira Janeiro Neves ${ }^{1 *}$; Ives Massanori Murata² ${ }^{2}$ Neusa Maria Colauto Stenzel²; \\ Cristiane de Conti Medina ${ }^{1}$; Andrey Vetorelli Borges ${ }^{1}$; Sergio Hideki Okumoto ${ }^{1}$; Roberto Huo \\ Chian Lee ${ }^{1}$; Hernandes Takeshi Kanai ${ }^{1}$ \\ ${ }^{1}$ UEL - Depto. de Agronomia, C.P. 6001 - 86051-990 - Londrina, PR - Brasil. \\ ${ }^{2}$ IAPAR, C.P. 481 - 86001-970 - Londrina, PR - Brasil. \\ *Corresponding author 〈csvjneve@uel.br>
}

\begin{abstract}
Field studies on citrus roots are important for genetic selection of cultivars and for management practices such as localized irrigation and fertilization. To characterize root systems of six rootstocks, taking into consideration chemical and physical characteristics of a clayey Typic Hapludox of the Northern State of Paraná, this study was performed having as scion the 'IAC-5 Tahiti' lime [Citrus latifolia (Yu. Tanaka)]. The rootstocks 'Rangpur' lime (C. limonia Osbeck), 'Africa Rough' lemon (C. jambhiri Lush.), 'Sunki' mandarin [C. sunki (Hayata) hort. ex Tan.], Poncirus trifoliata (L.) Raf., 'C13' citrange [C. sinensis (L.) Osb. $\mathrm{x} P$. trifoliata (L.) Raf] and 'Catânia 2' Volkamer lemon (C. volkameriana Ten. \& Pasq.) were used applying the trench profile method and the SIARCS ${ }^{\circledast} 3.0$ software to determine root distribution. 'C-13' citrange had the largest root system. 'Volkamer' lemon and 'Africa Rough' lemon presented the smallest amount of roots. The effective depth for $80 \%$ of roots was $31-53 \mathrm{~cm}$ in rows and $67-68 \mathrm{~cm}$ in inter-rows. The effective distance of $80 \%$ of roots measured from the tree trunk exceeded the tree canopy for P. trifoliata, 'Sunki' mandarin, and 'Volkamer' and 'Africa Rough' lemons.

Key words: Citrus latifolia, root system, trench profile method, soil bulk density
\end{abstract}

\section{DISTRIBUIÇÃO DO SISTEMA RADICULAR DE PORTA-ENXERTOS PARA LIMA ÁCIDA 'TAHITI'}

\begin{abstract}
RESUMO: Estudos sobre o sistema radicular são importantes para seleção de material genético e orientação de tratos culturais, como irrigação localizada, adubação e manejo de solo. O objetivo deste trabalho foi avaliar a distribuição do sistema radicular de seis porta-enxertos cítricos em um Latossolo Vermelho distroférrico no Norte do Paraná, levando em conta os atributos químicos e físicos do solo. Foram avaliadas plantas com 11 anos de idade de lima ácida 'Tahiti', clone IAC-5 [Citrus latifolia (Yu. Tanaka)] enxertadas nos seguintes porta-enxertos: limão 'Cravo' ( $C$. limonia Osbeck), limão 'Rugoso da África' $(C$. jambhiri Lush.), tangerina 'Sunki' [C. sunki (Hayata) hort. ex Tan.], Poncirus trifoliata (L.) Raf., citrange 'C13' [C. sinensis (L.) Osb. x P. trifoliata (L.) Raf] e limão 'Volcameriano' (C. volkameriana Ten. \& Pasq.), clone Catânia 2. Utilizou-se o método da trincheira e a quantificação das raízes foi feita em imagens digitais com o programa SIARCS ${ }^{\circledR}$. O citrange ‘C13' apresentou a maior quantidade de raízes e os limões 'Volcameriano' e 'Rugoso da África' tiveram as menores quantidades. A profundidade efetiva, até onde se encontram $80 \%$ das raízes, foi de 31 a $53 \mathrm{~cm}$ na linha de plantio e de 67 a $68 \mathrm{~cm}$ na entrelinha. A distância efetiva, até onde se encontram $80 \%$ das raízes a partir do tronco, na entrelinha ultrapassou o raio da copa das árvores para $P$. trifoliata, tangerina 'Sunki' e limões 'Volcameriano' e 'Rugoso da África'.

Palavras-chave: Citrus latifolia, raízes, método da trincheira, densidade do solo
\end{abstract}

\section{INTRODUCTION}

Rootstocks are important in relation to plant support and water or nutrient absorption from the soil. In the case of citrus, rootstocks are responsible for important characteristics of the plants, like tolerance to hydric stress, to high soil acidity, and to high aluminium saturation (Pace \& Araujo, 1986; Pompeu Jr., 1991). Performance of rootstocks in a certain environment is related to total volume, configuration, lateral distribution and depth of the root system (Cintra et al., 1999).
Studies on root systems have shown great differences among species in shape, quantity, root depth, and susceptibility to soil compaction (Kemper, 1981). Root systems can be restricted in compacted soils and the development can be affected in acid soils, as a result of decreasing nutrient absorption, caused by toxic elements as aluminium, or nutrient deficiency, mainly phosphorus and calcium (Anghinoni \& Meurer, 1999).

Most fruit tree roots grow approximately $200 \mathrm{~cm}$ horizontally, and the largest concentration of radicels occupies a $50 \mathrm{~cm}$ deep layer (Atkinson, 1980). Citrus 
roots can reach $120-150 \mathrm{~cm}$ in depth in well-drained soils; however, the largest concentration is found in the 60-90 cm layer (Montenegro, 1960; Jones \& Embleton; 1973; Moreira, 1983).

Growing rates, extension, distribution and total volume of roots consist fundamental information to improve management practices, such as local watering and tillage (Castle et al., 1989; Neves et al., 1998; Carvalho et al., 1999; Machado \& Coelho, 2000). There are few studies on root systems of citrus rootstocks in Brazil, and most of the existing were performed in São Paulo (Montenegro, 1960; Vieira \& Gomes, 1999), Rio de Janeiro (Pace \& Araujo, 1986) and Sergipe (Cintra et al., 1999). This project characterizes the distribution of the root systems of six Citrus rootstocks under 'Tahiti' lime scions, considering chemical and physical aspects of a Typic Hapludox, in Northern State of Paraná, Brazil.

\section{MATERIAL AND METHODS}

The citrus orchard was cultivated in Maringá, Northern State of Paraná, 2325'31"S and 51 ${ }^{\circ} 56^{\prime} 19^{\prime \prime} \mathrm{W}$; climate Cfa, subtropical humid, according to Köppen's classification; altitude $500 \mathrm{~m}$; annual mean temperature $21^{\circ} \mathrm{C}$, annual rainfall $1500 \mathrm{~mm}$; and $7.05 \mathrm{~h}_{\text {day }}{ }^{-1}$ of direct sunshine (Corrêa et al., 1982). 'IAC-5 Tahiti' lime [Citrus latifolia (Yu. Tanaka)] was used as scion and the following rootstocks were evaluated: 'Rangpur' lime $(C$. limonia Osbeck), 'Africa Rough' lemon (C. jambhiri Lush.); 'Sunki' mandarin [C. sunki (Hayata) hort. ex Tan.]; Poncirus trifoliata (L.) Raf.; 'C13' citrange [C. sinensis (L.) Osb. x P. trifoliata (L.) Raf]; and 'Catânia 2' Volkamer lemon (C. volkameriana Ten. \& Pasq.).

The orchard was set up in December, 1988, in $8 \mathrm{x}$ $6 \mathrm{~m}$ spacing, on tilled and limed soil ( 5 ton ha ${ }^{-1}$, divided in two applications). Weeds control was done by manual hoeing up to the third year after orchard implantation. From this period on, a weed mower was used in inter-rows and hand hoeing and residual herbicide application in plant rows. Liming with dolomitic lime $\left(5130 \mathrm{~kg} \mathrm{ha}^{-1}\right.$ in 1998 , and $2977 \mathrm{~kg} \mathrm{ha}^{-1}$ in August, 1999) and mineral fertilization were made according to Vitti (1990). Phyto-sanitary treatments were performed whenever necessary.

Plant roots were evaluated using the trench profile method (Böhm, 1979) during first semester of 2000, when plants were 11 years old. Three plants were evaluated per treatment, using one trench per plant. Trenches were $1.0 \mathrm{~m}$ deep, $3.0 \mathrm{~m}$ along row, and $4.0 \mathrm{~m}$ along inter-row (covering half spacing). Profile walls were leveled and visible roots were cut to standardize their length; $2 \mathrm{~mm}$ diameter roots were exposed, using a cylinder scarifier, composed of $1 \mathrm{~cm}$-long clout nails painted with white latex paint for larger contrast between soil and roots (Jorge et al., 1996). Roots with more than $2 \mathrm{~mm}$ of diameter (visual classification) were not painted. A wooden frame, divided into $25 \times 25 \mathrm{~cm}$ squares by a nylon thread, was fixed to the soil profile wall and each square was filmed (Cintra \& Neves, 1996).

After filming all squares, images were digitized by an IBM-PC digitalizing board (512 x 512 pixels; 256 tones of grey). Images were processed to determine root area in each square with the aid of the Integrated System for Root and Soil Coverage Analysis (SIARCS ${ }^{\circledR}$ ) software (Crestana et al., 1994). Root area for each depth and total area of roots in the planting row and inter-row profile were calculated. Since squares measured $25 \times 25 \mathrm{~cm}$, removing a soil layer of nearly $1 \mathrm{~cm}$, each square represented $625 \mathrm{~cm}^{2}$ of soil volume. Effective depth and effective distance were also calculated, corresponding to depth and distance from the trunk, that concentrated $80 \%$ of the evaluated roots (Klar, 1991).

Triplicate samples for soil chemical (Pavan et al., 1992) and physical (soil bulk density and granulometry) analyses were collected directly from the trenches: $0-25$; $25-50$; 50-75 and 75-100 cm layers, at distances of 125 and $375 \mathrm{~cm}$ from the trunk in the inter-row, and at 100 and 275 $\mathrm{cm}$ for rows. Undisturbed samples for soil density analysis were collected by $4.05 \mathrm{~cm}$ high and $5.54 \mathrm{~cm}$ diameter metallic rings. Resistance to penetration was evaluated using a hand penetrometer (Mhyre et al., 1984) at points close to samplings for chemical and density analyses.

The experimental was jet up in a randomized blocks design, with six treatments (rootstocks) and three replicates. The Duncan test $(P=0.05)$ was used to compare quantities of roots, root effective depth, root effective distance and tree canopy radius. To evaluate horizontal distribution of roots in inter-rows, among rootstocks, was used the Spearman correlation coefficient $(P=0.05)($ Levin, 1987).

\section{RESULTS AND DISCUSSION}

No difference was observed in the amount of roots among rootstocks for the planting row, at the $0-25$ and $25-50 \mathrm{~cm}$ depths (Table 1). 'C13' citrange and $P$. trifoliata were superior to 'Volkamer' lemon, for the 50$75 \mathrm{~cm}$ layer. ' $\mathrm{C} 13$ ' citrange presented more roots in the $75-100 \mathrm{~cm}$ depth, similarly to $P$. trifoliata, while 'Africa Rough' lemon and 'Volkamer' lemon presented the smallest amounts. In the inter-row, there was a difference only for the 25-50 cm depth, between 'C13' citrange, with larger quantity of roots, and 'Rangpur' lime, 'Volkamer' lemon and 'Africa Rough' lemon rootstocks.

'C13' citrange had the largest root system, in the row and total (Table 1), reflecting its superiority at different depths, differing from the 'Volkamer' lemon. For total roots in the inter-row, ' $\mathrm{C} 13$ ' citrange presented a larger quantity in relation to 'Africa Rough' lemon. Pace \& Araújo (1986) studying rootstock roots of 'Natal' orange ( $C$. sinensis L. Osbeck), observed that the 
Table 1 - Root area of rootstocks for 'Tahiti' lime in four depths, in the planting row, inter-row, and total (row + inter-row).

\begin{tabular}{|c|c|c|c|c|c|c|c|}
\hline \multirow[b]{2}{*}{ Depth $(\mathrm{cm})$} & \multicolumn{7}{|c|}{ Rootstock } \\
\hline & $\begin{array}{l}\text { 'Rangpur' } \\
\text { lime }\end{array}$ & $\begin{array}{c}\text { 'Africa } \\
\text { Rough' lemon }\end{array}$ & $\begin{array}{l}\text { 'Sunki' } \\
\text { mandarin }\end{array}$ & P. trifoliata & 'C13' citrange & $\begin{array}{l}\text { 'Volkamer' } \\
\text { lemon }\end{array}$ & C.V. $(\%)$ \\
\hline & \multicolumn{7}{|c|}{ Root area $\left(\mathrm{cm}^{2}\right)$ in planting row } \\
\hline $0-25$ & $194.17 \mathrm{a}$ & $184.94 \mathrm{a}$ & $181.23 \mathrm{a}$ & $164.05 \mathrm{a}$ & $207.27 \mathrm{a}$ & $92.13 \mathrm{a}$ & 40.38 \\
\hline $25-50$ & 30.93 a & $32.27 \mathrm{a}$ & 87.81 a & $65.85 \mathrm{a}$ & $57.29 \mathrm{a}$ & $13.15 \mathrm{a}$ & 89.08 \\
\hline $50-75$ & $18.10 \mathrm{abc}$ & $12.15 \mathrm{bc}$ & $14.72 \mathrm{abc}$ & $23.05 \mathrm{ab}$ & $33.01 \mathrm{a}$ & $4.39 \mathrm{c}$ & 53.44 \\
\hline $75-100$ & $16.24 \mathrm{bc}$ & $8.85 \mathrm{~cd}$ & $13.13 \mathrm{c}$ & $21.36 \mathrm{ab}$ & $27.19 \mathrm{a}$ & $5.31 \mathrm{~d}$ & 26.07 \\
\hline Total & $259.45 \mathrm{ab}$ & $238.22 \mathrm{ab}$ & $296.89 \mathrm{ab}$ & $274.32 \mathrm{ab}$ & 324.77 a & $114.99 \mathrm{~b}$ & 39.87 \\
\hline \multicolumn{8}{|c|}{ Root area $\left(\mathrm{cm}^{2}\right)$ in planting inter-row } \\
\hline $0-25$ & 124.66 a & $104.40 \mathrm{a}$ & 170.49 a & 183.59 a & 190.48 a & $133.52 \mathrm{a}$ & 39.19 \\
\hline $25-50$ & $54.83 \mathrm{~b}$ & $55.36 \mathrm{~b}$ & $95.97 \mathrm{ab}$ & $93.92 \mathrm{ab}$ & $158.80 \mathrm{a}$ & $55.23 \mathrm{~b}$ & 48.46 \\
\hline $50-75$ & $44.20 \mathrm{a}$ & $44.13 \mathrm{a}$ & 65.48 a & 50.15 a & $96.13 \mathrm{a}$ & $44.03 \mathrm{a}$ & 47.11 \\
\hline $75-100$ & $30.34 \mathrm{a}$ & $26.41 \mathrm{a}$ & $48.56 \mathrm{a}$ & $4.19 \mathrm{a}$ & $49.12 \mathrm{a}$ & 299.99 a & 38.94 \\
\hline Total & $254.0 \mathrm{ab}$ & $230.30 \mathrm{~b}$ & $380.50 \mathrm{ab}$ & $371.80 \mathrm{ab}$ & $494.50 \mathrm{a}$ & $262.80 \mathrm{ab}$ & 39.17 \\
\hline General Total & $513.4 \mathrm{ab}$ & $468.50 \mathrm{ab}$ & $677.30 \mathrm{ab}$ & $646.20 \mathrm{ab}$ & $816.00 \mathrm{a}$ & $377.80 \mathrm{~b}$ & 33.72 \\
\hline
\end{tabular}

Means followed by a common letter, in each line, do not differ by Duncan test $(P=0.05)$

'Volkamer' lemon presented a larger root system than the 'Rangpur' lime and the $P$. trifoliate, in a podzolic soil. Probably these results diverge because of the different types of soils and scions used in both experiments, hence these factors interfere in the vigor and root distribution (Montenegro, 1960).

In another trial performed in the same experimental orchard, 'C13' citrange, which presented more roots, also had larger fruit yield, in relation to other rootstocks (Stenzel, 1998). Therefore considering the conditions of where this study took place, plants benefited from a larger amount of roots. In Northern State of Paraná, rainfall $(1500 \mathrm{~mm})$ is concentrated between September and March, the same period of the vegetative development and production of the 'Tahiti' lime. The volume of roots can, however, be of no significance, depending on local conditions. In places where long drought periods occur, large root volume can be a negative characteristic. Cintra et al. (1999; 2000) observed, in Northeastern Brazil, that the 'Cleopatra' mandarin and the 'Rough' lemon had large root systems, leading to accelerated use of the soil water stock and, consequently, to a longer period of hydric stress. However, studying 'Pera' orange trees, Cintra et al. (2000) concluded that plant water loss depends also on leaf area and scion type.

For the $0-25 \mathrm{~cm}$ layer, the amount of roots in the row was larger than in the inter-row, except for $P$. trifoliata and 'Volkamer' lemon (Table 1), even though the length of trenches were $3 \mathrm{~m}$ in the row and $4 \mathrm{~m}$ in the inter-row. Soil moisture could have interfered in root quantity in the superficial layer, since this difference can be attributed to a favorable environment for root development, provided by the high moisture prevailing under the tree canopy. The dense canopy formed in the plant- ing row, between two plants, reduces soil water losses by evaporation, forming a favorable environment for root development, as compared to the inter-row (Castle, 1980). For deeper soil layers $(50-75$ and $75-100 \mathrm{~cm})$, the largest concentration of roots was observed in the inter-row, probably resulting from plant adaptation caused by the need of reaching water in deeper layers. Orchard interrow has higher evapo-transpiration, reducing the quantity of water stored in most superficial layers, because it is more exposed to sunlight and covered by native vegetation, since weed control was made by mower.

Granulometric analysis presented the following data, respectively, in clay, silt and sand $\left(\mathrm{g} \mathrm{kg}^{-1}\right): 0-25 \mathrm{~cm}$ layer: $600,70,330$; 25-50 cm layer: $620,70,310 ; 50-75$ cm layer: 610, 60, 330; 75-100 cm layer: 610, 60, 330 . The physical conditions of the soil (Table 2) probably contributed to increase root quantity of 'Rangpur' lime, 'Africa Rough' lemon, 'Sunki' mandarin and 'C13' citrange rootstocks in the row upper layer in relation to the same position in the inter-row. Traffic in the inter-row contributed to the increase in soil density and penetrometer resistance, reducing root growth. Development of Citrus plant roots is seriously affected when soil density is higher than $1.40 \mathrm{~kg} \mathrm{dm}^{-3}$ (Oliveira, 1991). Cintra et al. (1999) observed that increases of soil density from 1.291.35 to $1.44 \mathrm{~kg} \mathrm{dm}^{-3}$ induced reductions in 'Rangpur' lime tree and $P$. trifoliata radicels, occurring also reduction in aeration, water potential, and penetrometer resistance.

In relation to the chemical analysis of the soil, phosphorus content in the row was almost twice of that in the inter-row, presenting a decrease in deeper layers (Table 3). Large phosphorus contents in upper layers, are probably a result of the non-revolving soil operations and the low mobility of this nutrient in the soil (Ernani et al., 
Table 2 - Soil bulk density and penetrometer resistance at four depths in the planting row and inter-row (average 18 trenches).

\begin{tabular}{|c|c|c|c|c|}
\hline \multirow{2}{*}{ Trunk distance } & \multicolumn{2}{|c|}{ Soil bulk density } & \multicolumn{2}{|c|}{ Penetrometer resistance } \\
\hline & 100 & 275 & 100 & 275 \\
\hline $\mathrm{cm}$ & - & - & - - - & - \\
\hline \multicolumn{5}{|l|}{ Row } \\
\hline \multicolumn{5}{|l|}{ Depth } \\
\hline $0-25$ & 1.15 & 1.18 & 0.41 & 0.43 \\
\hline $25-50$ & 1.16 & 1.16 & 0.57 & 0.68 \\
\hline $50-75$ & 1.13 & 1.11 & 0.48 & 0.59 \\
\hline $75-100$ & 1.11 & 1.11 & 0.39 & 0.58 \\
\hline Inter-row & 125 & 375 & 125 & 375 \\
\hline \multicolumn{5}{|l|}{ Depth } \\
\hline $0-25$ & 1.23 & 1.35 & 1.27 & 2.05 \\
\hline $25-50$ & 1.21 & 1.25 & 1.41 & 1.33 \\
\hline $50-75$ & 1.12 & 1.15 & 1.04 & 0.83 \\
\hline $75-100$ & 1.14 & 1.12 & 0.73 & 0.72 \\
\hline
\end{tabular}

Table 3 - Soil chemical characteristics of the experimental area at four depths (average 18 trenches).

\begin{tabular}{|c|c|c|c|c|c|c|c|c|}
\hline Depth & $\mathrm{V}^{1}$ & $\mathrm{CEC}^{2}$ & $\mathrm{Ca}+\mathrm{Mg}$ & $\mathrm{K}$ & $\mathrm{Al}$ & $\begin{array}{c}\mathrm{pH} \\
\left(\mathrm{CaCl}_{2}\right)\end{array}$ & $\mathrm{P}$ & $\mathrm{OM}^{3}$ \\
\hline $\mathrm{cm}$ & $\%$ & \multicolumn{5}{|c|}{ - $\mathrm{mmol}_{\mathrm{C}} \mathrm{dm}^{-3} \ldots \ldots$} & $\mathrm{mg} \mathrm{dm} \mathrm{d}^{-3}$ & $\mathrm{~g} \mathrm{dm}^{-3}$ \\
\hline \multicolumn{9}{|c|}{ 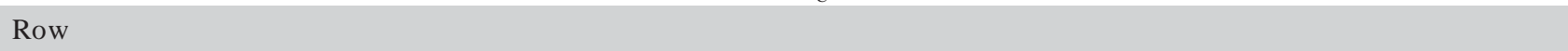 } \\
\hline $0-25$ & 35 & 50.10 & 29.80 & 3.80 & 4.30 & 4.61 & 18.28 & 20.40 \\
\hline $25-50$ & 10 & 28.60 & 8.60 & 2.50 & 16.30 & 3.94 & 2.42 & 17.27 \\
\hline $50-75$ & 8 & 27.70 & 6.90 & 1.90 & 19.60 & 3.91 & 1.92 & 14.52 \\
\hline $75-100$ & 9 & 27.20 & 7.80 & 1.50 & 17.60 & 3.94 & 2.74 & 13.25 \\
\hline \multicolumn{9}{|c|}{ Inter-row } \\
\hline $0-25$ & 37 & 38.10 & 30.60 & 4.50 & 4.10 & 4.56 & 10.09 & 19.28 \\
\hline $25-50$ & 11 & 26.90 & 9.00 & 2.70 & 16.70 & 3.93 & 4.70 & 16.53 \\
\hline $50-75$ & 9 & 29.20 & 8.20 & 1.80 & 18.70 & 3.90 & 2.29 & 14.74 \\
\hline $75-100$ & 10 & 26.90 & 8.40 & 1.40 & 17.60 & 3.93 & 1.72 & 18.76 \\
\hline
\end{tabular}

2001). This can also have contributed to an increase in the amount of roots in superficial layers in the row. The largest part of roots are found in the $0-15 \mathrm{~cm}$ depth, and this layer is the most important for plant nutrient supply, specially phosphorus, that stimulates root growth in layers fertilized with this nutrient (Anghinoni \& Meurer, 1999).

$\mathrm{Ca}$ and $\mathrm{Mg}$ contents and, consequently, base saturation $(\mathrm{V} \%)$ and cation exchange capacity (CEC) are also greater in the superficial soil layer (Table 3). The no incorporation of lime and the low mobility of $\mathrm{Ca}$ in the soil profile helped to increase the toxic aluminium concentration and to reduce $\mathrm{pH}$ below the $25 \mathrm{~cm}$ depth (Quaggio et al., 1998). At the $25-100 \mathrm{~cm}$ layer, Al contents (Table 3 ) are high, while $\mathrm{Ca}$ and $\mathrm{Mg}$ contents are very low, considering the standards used in the State (Paraná, 1989). This may have interfered with root development, because excess $\mathrm{Al}$ and low $\mathrm{Ca}$ content are important chemical barriers for root elongation and ramification (Ritchey et al., 1983).

Effective depth, which indicates the depth where $80 \%$ of roots are found, varied from $31 \mathrm{~cm}$ for the 'Volkamer' lemon and 'Africa Rough' lemon, to $53 \mathrm{~cm}$ for $P$. trifoliata and ' $\mathrm{C} 13$ ' citrange in the row, with no differences (Table 4). For the inter-row, the effective depth was $67-68 \mathrm{~cm}$ for all rootstocks. In this aspect, rootstocks can react differently in long water stress periods, due to the depth of the root system. In regions exposed to drought, rootstocks of deep soils develop larger, deeper root system (Koller, 1994). Vieira \& Gomes (1999) found $50 \mathrm{~cm}$ of effective depth for 'Rangpur' lime under 'Tahiti' lime, in an irrigated orchard. Machado \& Coelho (2000) found about $40 \mathrm{~cm}$ of effective depth in Piracicaba, $\mathrm{SP}$, with no irrigation. 
In relation of effective distance (Table 4), the 'Volkamer' lemon was inferior to the other rootstocks in the planting row, with $169 \mathrm{~cm}$, differing from the 'Rangpur' lime $(230 \mathrm{~cm})$, 'Africa Rough' lemon $(233 \mathrm{~cm})$, 'C13' citrange $(235 \mathrm{~cm})$ and P. trifoliata $(254 \mathrm{~cm})$. 'Sunki' mandarin $(207 \mathrm{~cm})$ did not differ from the others. In the planting inter-row, there was no difference among rootstocks. For the 'Rangpur' lime, results agree with Machado \& Coelho (2000) that found $225 \mathrm{~cm}$ of effective distance, also in a clayey soil, for 'Tahiti' lime scion.

Effective distance of roots were similar to tree canopy radia for all rootstocks (Table 4 and 5) in planting rows and inter-rows, indicating that there was a larger concentration of roots under the tree canopy. Root effective distance was larger than the tree canopy radius only for 'Africa Rough' lemon, P. trifoliata and 'Volkamer' lemon rootstocks. Machado \& Coelho (2000) also found effective distances smaller than tree canopy radia for 'Rangpur' lime rootstock for 'Tahti' lime.
The quantity of roots was correlated to their distance from the trunk in inter-rows (Table 6), signifying that root presence was noticed over tree canopy limit for $P$. trifoliata, with positive correlation between quantity of roots and distance from the trunk in all depths. 'Africa Rough' lemon, 'Sunki' mandarin and 'Volkamer' lemon rootstocks had also positive correlation between quantity of roots and distance from the trunk for the 25-50; 50-75 and 75-100 cm depths. 'Rangpur' lime had also this behavior for the $25-50$ and $50-75 \mathrm{~cm}$ layers, and the same happened to ' $\mathrm{C} 13$ ' citrange only for the $50-75 \mathrm{~cm}$ depth, and both of them had smaller root system than tree canopy radius. However, on P. trifoliata, 'Africa Rough' lemon, 'Sunki' mandarin and 'Volkamer' lemon rootstocks, results agree with fertilization and liming recommendations, which recomend fertilization of Citrus plants, after 3 years of age, in a band of width equal to the tree canopy radius, $2 / 3$ inside canopy projection and 1/3 outside (Grupo Paulista de Adubação e Calagem para Citros, 1994).

Table 4 - Root effective depth and effective distance of rootstocks for 'Tahiti' lime in the row and inter-row.

\begin{tabular}{|c|c|c|c|c|c|c|c|}
\hline & \multicolumn{7}{|c|}{ Rootstock } \\
\hline & 'Rangpur' lime & 'Africa Rough' lemon & 'Sunki' mandarin & P. trifoliata & 'C13' citrange & 'Volkamer' lemon & C.V. $(\%)$ \\
\hline \multicolumn{8}{|c|}{ Effective depth $(\mathrm{cm})$} \\
\hline Row & $45 \mathrm{a}$ & $31 \mathrm{a}$ & $44 \mathrm{a}$ & 53 a & 53 a & $31 \mathrm{a}$ & 26.40 \\
\hline Inter-row & $68 \mathrm{a}$ & $67 \mathrm{a}$ & 68 a & $67 \mathrm{a}$ & $67 \mathrm{a}$ & $68 \mathrm{a}$ & 3.62 \\
\hline \multicolumn{8}{|c|}{ Effective distance $(\mathrm{cm})$} \\
\hline Row & $230 \mathrm{a}$ & 233 a & $207 a b$ & $254 \mathrm{a}$ & $235 \mathrm{a}$ & $169 \mathrm{~b}$ & 11.14 \\
\hline Inter-row & $312 \mathrm{a}$ & 348 a & 318 a & 332 a & $325 \mathrm{a}$ & 348 a & 6.65 \\
\hline
\end{tabular}

Means followed by a common letter, in each line, do not differ by Duncan test $(P=0.05)$.

Table 5 - 'Tahiti’ lime canopy radius with different rootstocks. Maringá, PR, 2001.

\begin{tabular}{lccccccc}
\hline \multicolumn{7}{c}{ Rootstock } \\
\cline { 2 - 5 } & 'Rangpur' lime & 'Africa Rough' lemon & 'Sunki' mandarin & P. trifoliata & 'C13' citrange & 'Volkamer' lemon & C.V. (\%) \\
\hline Canopy radius $(\mathrm{cm})$ & $320 \mathrm{a}$ & $306 \mathrm{a}$ & $253 \mathrm{~b}$ & $280 \mathrm{ab}$ & $326 \mathrm{ab}$ & $316 \mathrm{a}$ \\
Row & $376 \mathrm{a}$ & $326 \mathrm{ab}$ & $286 \mathrm{~b}$ & $326 \mathrm{ab}$ & $363 \mathrm{a}$ & $320 \mathrm{ab}$ & 10.52 \\
\hline Inter-row & 375 &
\end{tabular}

Means followed by a common letter, in each line, do not differ by Duncan test $(P=0.05)$.

Table 6 - Correlation between horizontal distribution of roots of rootstocks for 'Tahiti' lime and trunk distance, at four depths, in the planting row and inter-row.

\begin{tabular}{|c|c|c|c|c|c|c|}
\hline \multirow[b]{2}{*}{ Depth } & \multicolumn{6}{|c|}{ Rootstock } \\
\hline & 'Rangpur' lime & 'Africa Rough' lemon & 'Sunki' mandarin & P. trifoliata & 'C13'citrange & 'Volkamer' lemon \\
\hline \multicolumn{7}{|l|}{$\mathrm{cm}$} \\
\hline $0-25$ & $\begin{array}{l}-0.435^{1} \\
(0.920)^{2}\end{array}$ & $\begin{array}{c}-0.388 \\
(0.137)\end{array}$ & $\begin{array}{c}-0.391 \\
(0.134)\end{array}$ & $\begin{array}{c}0.670 \\
(0.004)\end{array}$ & $\begin{array}{l}-0.258 \\
(0.333)\end{array}$ & $\begin{array}{c}0.255 \\
(0.338)\end{array}$ \\
\hline $25-50$ & $\begin{array}{c}0.611 \\
(0.011)\end{array}$ & $\begin{array}{c}0.879 \\
(0.000)\end{array}$ & $\begin{array}{c}0.741 \\
(0.001)\end{array}$ & $\begin{array}{c}0.782 \\
(0.000)\end{array}$ & $\begin{array}{c}0.464 \\
(0.069)\end{array}$ & $\begin{array}{c}0.761 \\
(0.000)\end{array}$ \\
\hline $50-75$ & $\begin{array}{c}0.647 \\
(0.006)\end{array}$ & $\begin{array}{c}0.757 \\
(0.000)\end{array}$ & $\begin{array}{c}0.744 \\
(0.000)\end{array}$ & $\begin{array}{c}0.955 \\
(0.000)\end{array}$ & $\begin{array}{c}0.685 \\
(0.003)\end{array}$ & $\begin{array}{c}0.661 \\
(0.005)\end{array}$ \\
\hline $75-100$ & $\begin{array}{c}0.050 \\
(0.854)\end{array}$ & $\begin{array}{c}0.768 \\
(0.000)\end{array}$ & $\begin{array}{c}0.608 \\
(0.012)\end{array}$ & $\begin{array}{c}0.758 \\
(0.000)\end{array}$ & $\begin{array}{c}0.479 \\
(0.060)\end{array}$ & $\begin{array}{c}0.764 \\
(0.000)\end{array}$ \\
\hline
\end{tabular}

${ }^{1}$ Values superior to 0.60 show strong association averages.

${ }^{2} \mathrm{P}$-values equal or inferior to 0.05 indicates that the hipothesys of nule coeficient is rejected (5\% significance level); P-values superior to 0.05 indicates no correlation. 


\section{ACKNOWLEDGMENTS}

To Wandayr Corrêa (IAPAR), Édson Takeshi Koike, Marcelo Sumiya and Marcos Yutaka Yano (UEL) for help in data collection, and to CAPES and CNPq for financial support.

\section{REFERENCES}

ANGHINONI, I.; MEURER, E. J. Eficiência de absorção de nutrientes pelas raízes. In: WORKSHOP SOBRE SISTEMA RADICULAR: METOlOGIAS E ESTUDO DE CASOS, 1., Aracaju, 1999. Anais. Aracaju: EMBRAPA, 1999. p.57- 87.

ATKINSON, D. The distribution and effectiveness of the roots of tree crops. Horticultural Reviews, v.2, p.424-490, 1980.

BÖHM, W. Methods of studying root systems. Berlin: Springer-Verlag, 1979. $188 \mathrm{p}$

CARVALHO, J.E.B. de; SOUZA, L. da S.; JORGE, L.A. de C.; RAMOS, W.F.; NETO, A. de O.C.; ARAÚJO, A.M. de A.; LOPES, L.C.; JESUS, M.S. de. Manejo de cobertura do solo e sua interferência no desenvolvimento do sistema radicular da laranja 'Pêra'. Revista Brasileira Fruticultura, v.21, p.140-145, 1999.

CASTLE, W.S. Fibrous root distribution of 'Pinaple' Orange trees on Rough Lemon rootstock at three tree spacings. Journal of the American Society for Horticultural Science, v.105, p.478-480, 1980.

CASTLE, W.S.; TUCKER, D.R.H.; KREZDORN, A.H.; YUTSEY, C.O. Rootstocks for Florida citrus: rootstock selection the first step to success. Gainesville: University of Florida, Institute of Food and Agricultural Sciences, 1989. 48p.

CINTRA, F.L.D.; NEVES, C.S.V.J. Aspectos metodológicos do estudo do sistema radicular de plantas perenes através de imagens. Boletim Informativo da Sociedade Brasileira de Ciência do Solo, v.21, p.9194, 1996.

CINTRA, F.L.D.; LIBARDI, P.L.; JORGE, L.A.C. Distribuição do sistema radicular de porta-enxertos de citros em ecossistema de tabuleiro costeiro. Revista Brasileira de Fruticultura, v.21, p.313-317, 1999.

CINTRA, F.L.D.; LIBARDI, P.L.; SAAD, A.M. Balanço hídrico no solo para porta-enxertos de citros em ecossistema de Tabuleiro Costeiro. Revista Brasileira de Engenharia Agrícola e Ambiental, v.4, p.2328, 2000.

CORRÊA, A.R.; GODOY, H.; BERNARDES, R.L.M. Características climáticas de Londrina. 2.ed. Londrina: IAPAR, 1982. 16p. (Circular Técnica, 5).

CRESTANA, S.; GUIMARÃES, M.F.; JORGE, L.A.C.; RALISCH, R.; TOZZI, C.L.; TORRE, A.; VAZ, C.M.P. Avaliação da distribuição de raízes no solo auxiliada por processamento de imagens digitais. Revista Brasileira de Ciência do Solo, v.18, p.365-371, 1994.

ERNANI, P.R.; STECKLING, C.; BAYER, C. Características químicas de solo e rendimento de massa seca de milho em função do método de aplicação de fosfatos, em dois níveis de acidez. Revista Brasileira de Ciência do Solo, v.25, p.939-946, 2001.

GRUPO PAULISTA DE ADUBAÇÃO E CALAGEM PARA CITROS GPACC. Recomendações de adubação e calagem para citros no estado de São Paulo. Laranja, v.15 p.1- 27, 1994. (n. esp.)

JONES, W.W.; EMBLETON, T.W. Soil management and cover crops. In: REUTHER, W. (Ed.) The citrus industry. Riverside: University of California, 1973. v.3, p.98-121.

JORGE, L.A.C.; RALISCH, R.; ABI SAAB, O.J.G.; MEDINA, C.C.; GUIMARÃES, M.F.; NEVES, C.S.V.J.; CRESTANA, S.; CINTRA, F.L.D.; BASSOI, L.H.; FERNANDES, S.B.V. Recomendações práticas para aquisição de imagens digitais analisadas através do SIARCS. São Carlos: EMBRAPA, CNPDIA, 1996. cap.1, p.1-27. (Circular Técnica, 1)

KEMPER, B. Soil compaction and root growth in Paraná. In: RUSSEL, R.S.; IGHE, K.; MEHTA, Y.R. The soil/root system in relation to brazilian agriculture. Londrina: Fundação IAPAR, 1981. p.81-101.
KLAR, A.E. Irrigação; freqüência e quantidade de aplicação. São Paulo: Nobel, 1991. 156p.

KOLLER, O.C. Citricultura; laranja, limão e tangerina. Porto Alegre: Rígel, 1994. 446p.

LEVIN, J. Estatística aplicada a ciências humanas. 2.ed. São Paulo: Habra, 1987. 391p.

MACHADO, C.C.; COELHO, R.D. Estudo da distribuição espacial do sistema radicular do limão 'Cravo' enxertado com lima ácida 'Tahiti'. Laranja, v.21, p.359-380, 2000.

MHYRE, D.L.; VÁSQUEZ, L.; PORTIER, K.M.; GARDNER, J.R.; MANSELL, R.S. Penetrometer resistance for soil in a Florida grove affected with citrus blight. In: INTERNATIONAL CITRUS CONGRESS, 6., São Paulo, 1984. Proceedings. São Paulo: International Society of Citriculture, 1984. v.1, p.134-140.

MONTENEGRO, H.W.S. Contribuição ao estudo do sistema radicular das plantas cítricas. Piracicaba, 1960. 143p. Universidade de São Paulo. Tese (Cátedra) - Escola Superior de Agricultura "Luiz de Queiroz", Universidade de São Paulo.

MOREIRA, C.S. Estudo da distribuição do sistema radicular da laranjeira 'Pera' Citrus sinensis (L.) Osbeck, com diferentes manejos de solos. Piracicaba: USP/ESALQ, 1983. 97p. (Tese - Livre Docência).

NEVES, C.S.V.J.; DECHEN, A.R.; FELLER, C.; ABI SAAB, O.J.G.; PIEDADE, S.M.S. Efeito do manejo do solo no sistema radicular de tangerineira 'Poncã' enxertada sobre limoeiro 'Cravo' em Latossolo roxo. Revista Brasileira de Fruticultura, v.20, p.146-253, 1998.

OLIVEIRA, J.B. Solos para citros. In: RODRIGUEZ, O.; VIEGAS, F.C.P.; POMPEU JR., J.; AMARO, A.A. (Ed.) Citricultura brasileira. 2.ed. Campinas: Fundação Cargill, 1991. v.1, p.206-227.

PACE, C.A.M.; ARAÚJO, C.M. Estudo da distribuição do sistema radicular de porta-enxertos cítricos em solos podzolizados e sua relação com a formação de copas. In: CONGRESSO BRASILEIRO DE FRUTICULTURA, 8., Brasília, 1986. Anais. Brasília: Sociedade Brasileira de Fruticultura, 1986. v.1, p.199-205.

PARANÁ. (Estado). Secretaria de Agricultura e do Abastecimento. Manual técnico do subprograma de manejo e conservação do solo. Curitiba: SEAB, 1989. 306p.

PAVAN, M.R.A.; BLOCK, M.S.; ZEMPULSKI, H.C.; MIYAZAWA, M.I ZOCOLER, D.C. Manual de análise química de solo e controle de qualidade. Londrina: IAPAR, 1992. 40p. (Circular, 76).

POMPEU JR., J. Porta-enxertos. In: RODRIGUEZ, O.; VIEGAS, F.C.P.; POMPEU JR., J.; AMARO, A.A. (Ed.) Citricultura brasileira. 2.ed. Campinas: Fundação Cargill, 1991. v.1, p.265-280

QUAGGIO, J.A.; ROSA, S.M.; MATTOS JR., D.; RAIJ, B.van. Resposta da laranjeira 'Valência' à aplicação de calcário e gesso. Laranja, v.19, p.383-398, 1998.

RITCHEY, K.D.; SILVA, J.E.; SOUZA, D.M.G. Relação entre teor de cálcio no solo e desenvolvimento de raízes avaliado por um método biológico. Revista Brasileira de Ciência do Solo, v.7, p.269-275, 1983.

STENZEL, N.M.C. Comportamento de porta-enxertos para lima ácida 'Tahiti' no Estado do Paraná. In: CONGRESSO BRASILEIRO DE FRUTICUlTURA, 15., Poços de Caldas, 1998. Anais. Lavras: Sociedade Brasileira de Fruticultura, 1998. p.289.

VIEIRA, D.B.; GOMES, E.M. Determinação da profundidade efetiva do sistema radicular do limão 'Cravo' com copa de lima ácida 'Tahiti'. Laranja, v.20, p.419-431, 1999.

VITTI, G.C. Nutrição e Adubação de Pomares. In: ENCONTRO PARANAENSE DE CITRICULTURA. 2., Maringá, 1989. Anais. Maringá: Associação de Engenheiros Agrônomos do Paraná, 1990. p.104-119.

Received September 27, 2002 Accepted November 13, 2003 